\title{
= \\ JeAn-LuC Nancyn ONTOLOGIAN \\ EETOS JA PRAKSIS
}

Jean-Luc Nancy toteaa Etre singulier pluriel -teoksessaan painokkaasti, että hänen siinä hahmottelemansa singulaarisen pluraalisen olemisen ajattelun tai kanssaolemisen ontologian on oltava, ei vain filosofinen teoria, vaan yhtä lailla eetosta ja praksista (Nancy 1996: 87). Ontologian on siis oltava etiikkaa ja jonkinlaista toimintaa tai käytäntö. ${ }^{1}$ Ennen kuin pääsemme edes tarkemmin pohtimaan tämän väitteen mieltä, herää kysymys, mitä nämä termit - eetos, praksis ja lopulta itse ontologia - tässä yhteydessä oikein tarkoittavat. Miten niiden samastaminen tulisi ymmärtää?

Selvää on ainakin se, että ajattelu, joka ei tee eroa ontologian ja etiikan välillä, käyttää näitä termejä viittaamaan johonkin muuhun kuin mitä kyseisten hakusanojen kohdalta löytyy filosofian sanakirjoista. Eräs sanakirja toteaa ontologian olevan "filosofian alue, joka tutkii olemisen ja olemassaolon käsitteitä ja olevaisen perimmäistä laatua", etiikan se taas mainitsee olevan "moraalifilosofiaa", siis "filosofian haara, joka yleiseltä kannalta selvittelee ihmisten tekojen, pyrkimysten ja arvostusten hyväksyttävyyttä ja tuomittavuutta" ${ }^{2}$ - eli toisin sanoen ontologia ja etiikka nähdään filosofisina oppialoina, jotka erottaa toisistaan se, että niillä on eri kohteet. Kyse on siis tietämisestä, sen tietämisestä mitä olevainen on ja toisaalta mikä on hyvää tai pahaa"yleisellä tasolla", objektiivisesti, siis teoreettisesta tietämisestä. Näin ajattelu samalla erotetaan käytännön toiminnasta tai Nancyn mainitsemasta praksiksesta. ${ }^{3}$
Kuten tunnettua, ainakin mannermaisen ajattelun piirissä filosofian jakautuminen tällä tavalla eri oppialoiksi ja itse asiassa myös ajatus siitä, että filosofia tavoittelee ensisijaisesti tietoa, vaikka sitten tietoa totuudesta, on jo pitkään kyseenalaistettu. Eri ajattelijoiden, ajattelusuuntausten ja jopa koko filosofian kohdalla on puhuttu niin sanotusta eettisestä käänteestä, jonka myötä kysymys etiikasta ymmärrettynä joksikin aivan muuksi kuin moraalifilosofiaksi on noussut ensisijaisen tärkeäksi, ja esimerkiksi Emmanuel Levinas nosti etiikan jopa "ensimmäiseksi filosofiaksi" (ks. esim. Levinas 1996). Ehkä tärkein taustatekijä tässä on Martin Heideggerin ajattelu, tai vähintäänkin se on Nancyn pääasiallinen viitepiste, kun hän julistaa, että ontologian on oltava etiikkaa.

Heidegger nimenomaan hylkäsi etiikan tai moraalifilosofian oppialana, mutta siitä huolimatta - tai juuri siksi - hänen "olemisen ajattelunsa" on, kuten Nancykin osoittaa, samalla erottamattomasti "alkuperäistä etiikkaa". ${ }^{4}$ Heidegger pohtii "Kirjeessä 'humanismista" (Heidegger 2000a: 51-107) (johon Nancynkin analyysi suurimmalta osin perustuu), mitä mieltä, jos mitään, on kysymyksellä etiikan ja ontologian suhteesta. Ennen kuin tätä suhdetta voidaan yrittää määritellä, Heidegger toteaa, pitäisi tietää mitä" ontologia" ja "etiikka" tarkoittavat. Ja jos kävisi ilmi, että opinaloina niillä ei ole mitään tekemistä ajattelun todellisen tehtävän kanssa, mitä tälle kysymykselle itselleen tapahtuisi? Heideggerin tulkinnan mu- 
kaan etiikka opinalana syntyi yhdessä logiikan ja fysiikan kanssa Platonin koulussa, aikaan jolloin - edelleen Heideggerin mukaan - ajattelu alkoi muuttua filosofiaksi ja filosofia taas tieteeksi. Tätä aikaa edeltävät ajattelijat eivät siis tunteneet "logiikkaa" tai "etiikkaa", mutta tämä ei tarkoita sitä, että he olisivat olleet epäloogisia tai moraalittomia. Päinvastoin, Heidegger löytää heidän ajattelustaan jotain syvempää, alkuperäisempää, joka on myöhemmin päässyt unohtumaan erityisesti sen tähden, että ajattelu on tulkittu "teknisesti" tai välineellisesti. ${ }^{5}$

Tämä "alkuperäinen èthos" näkyy Heideggerin mukaan erityisen selvästi eräässä $\mathrm{He}^{-}$ rakleitoksen fragmentissa, joka kuuluu seuraavasti: êthos anthrōpō daimōn, "ihmisen omin luonne on hänen daimoninsa". Heideggerin mukaan tavallinen tapa kääntää tämä fragmentti kertoo kuitenkin vain modernista ajattelutavasta eikä tavoita sitä, mitä se kreikkalaisille merkitsi. Pikemmin kuin "omimmaksi luonteeksi", joka koituu ihmisen kohtaloksi, èthos pitäisi ajatella (sanan vähemmän tunnetun merkityksen mukaisesti) "asuinsijaksi": se nimeää "sen avoimen alueen, jossa ihminen asuu". (Heidegger 2000a: 96.)

Heidegger kirjoittaa edelleen, että"[j]os sanan èthos perusmerkityksen mukaisesti etiikka tarkoittaa ihmisen asuinsijan pohdiskelemista, niin olemisen totuuden ajatteleminen eksistoivan ihmisen alkuelementtinä on jo itsessään alkuperäistä etiikkaa" (Heidegger 2000a: 98). Alkuperäistä etiikkaa on siis ajattelu, joka pohtii eetosta olemisen totuutta koskevana ja sen mukaisena käyttäytymisenä. Koska siinä on pelissä suhde olemisen totuuteen, tai Nancyn sanoin mieleen, se on paitsi perustavampaa kuin etiikka, myös perustavampaa kuin ontologia, joka Heideggerin mukaan keskittyy ajattelemaan"olevaa olemisessaan" ja unohtaa kysymyksen olemisen totuudesta. Juuri siksi Heidegger kutsui Olemisessa ja ajassa ajatteluaan"fundamentaaliontologiaksi". (Heidegger 2000a: 98-99; Nancy 1998: 48.) Näin käykin Nancyn mukaan ilmeiseksi, että olemisen ajattelu edellyttää etiikkaa,ja vielä radikaalimmin, että sen itsensä on oltava etiik- kaa. Itse asiassa "alkuperäinen etiikka" on Nancyn mukaan Heideggerin ajattelulle oikeampi nimitys kuin "fundamentaaliontologia", sillä etiikka on nimenomaan se, mikä fundamentaaliontologiassa on perustavanlaatuista tai" fundamentaalista". (Nancy 1998: 48-49.) Ontologiaa ei kuitenkaan voi tuosta vain korvata etiikalla - tai toisin sanoen termit eivät ole vaihdettavissa keskenään - sillä tällöin oltaisiin vaarassa kadottaa näkyvistä eräs aivan keskeinen seikka, nimittäin se että

eetos ei ole mitään olemiselle ulkopuolista tai siihen ulkoa tuotua. Se ei tule olemisen lisäksi tai oheen, eikä se anna olemiselle muualta tuotuja sääntöjä. Sen sijaan oleminen on - koska se ei ole mitään olevaa - se mikä ek-sistoi olemassaolevaa ja se mikä panee sen alttiiksi (expose) mielekkyydelle (Nancy 1998: 49).

Mieli (tai eetos) ei siis ole mitään, mikä jälkikäteen tai ulkoa käsin lisättäisiin johonkin itsessään mykkään ja mielettömään ”olemisen raakaan tosiasiaan". Ja niin ontologia ja etiikka lankeavat yhteen pisteessä, jossa oleminen itse on mieltä, mielen suhdetta tai sitä koskevaa toimintaa. Palaan tähän tuonnempana, mutta nyt on syytä tutkia vielä Nancyn toista samastusta: ontologia, olemisen ajattelu, ei ole vain etiikkaa vaan myös toimintaa.

Jo mainitussa "Humanismikirjeessä" Heidegger päätyy siihen, ettei olemisen totuutta kysyvä ajattelu ole etiikkaa eikä ontologiaa, sillä, kuten todettu, se mitä se pyrkii ajattelemaan edeltää tällaisia jaotteluja. Mutta entä jos kysymys esitettäisiin toisin? Jos tämä ajattelu siis määrittää ihmisyyden olemuksen eksistenssiksi, suhteeksi omaan olemiseen, onko tämä vain ihmistä koskevaa teoreettista tietoa vai voiko sen nojalla muotoilla käytännöllisiä, praktisia elämänohjeita? Heideggerin vastaus on, ettei olemisen ajattelu ole teoreettista eikä käytännöllistä, vaan se edeltää myös näitä erotteluja. Se ylittää kaiken teoreettisen tarkastelun, sillä sen huolena on se aukeama tai "valo", joka vasta sallii teoreettisen katseen nähdä. (Hei- 
degger 2000a: 99-104). Eikä se ole myöskään käytännöllistä siinä mielessä, että se tuottaisi tulosta, saisi aikaan konkreettisia vaikutuksia maailmassa - Heidegger toteaa ykskantaan, että "[t]ällainen ajattelu ei johda tuloksiin" (Heidegger 2000a: 100).

Ja aivan erityisesti se ei tarjoa toiminnan ohjenuoria, sillä se koskee sitä ulottuvuutta, jossa kysymys "mitä minun tulee tehdä?" vasta nousee esiin. Teorian ja käytännön vastakohdan tuolla puolen olemisen ajattelu kuitenkin on aivan erityislaatuista toimintaa tai teko, tai kuten Nancy tulkitsee, praksista tai "käyttäytymistä" (conduire, handeln). Siinä on näet kyse olemisen suhteesta ihmiseen, siis siitä kuinka ihminen tai Dasein - on se erikoislaatuinen oleva, jossa oleminen asettuu alttiiksi mielekkyytenä ja joka joutuu myös tuntemaan vastuunsa tästä mielestä. (Nancy 1998: 17-20, 36, 53). Itse asiassa tästä huomataan, että ajattelu nimenomaan $e i$ saakaan tarjota valmiita sääntöjä tai maksiimeja, valmista mieltä omaksuttavaksi: silloin se nimenomaan tukahduttaisi tämän alkuperäisen mielekkyyden tilan. Tehtävä on sen sijaan ajatella sitä, mikä asettaa ihmisen asemaan, jossa hänen on luotava tai valittava arvonsa ja norminsa. (Nancy 1998: 13, 49.) Se mikä olemisen ajattelussa siis on eettistä tai praktista on "alkuperäisempää"kuin filosofian jakautuminen etiikkaan, ontologiaan ja niin edelleen, ja myös "alkuperäisempää" kuin teorian ja käytännön erottelu, sillä se koskee sitä mielekkyyden ulottuvuutta, joka vasta mahdollistaa tällaisten merkityskokonaisuuksien luomisen.

Nyt voidaankin sanoa, että ontologian määritteleminen eetokseksi ja praksikseksi tarkottaa sitä, että olemisen ajatteleminen on heti, erottamattomasti, myös eettisen ja toimivan suhteen avautumista tähän olemiseen. Se ei voi tarkastella kohdettaan ulkoa käsin ikään kuin pelkästä tieteellisestä mielenkiinnosta, vaan se on sitoutumista ja vastuuta, vastaamista mielen vetoomukseen, mieltä koskevan ehdottoman vastuun kokemista.

Omaa ontologista projektiaan Nancy kuvaa myös toisista lähtökohdista. Hän sanoo haluavansa - ja korostaa, että kyse ei ole vain henkilökohtaisesta kunnianhimosta vaan välttämättömyydestä tai velvollisuudesta, joka koskee meitä kaikkia - kirjoittaa uudestaan koko "ensimmäisen filosofian" singulaarisen pluraalisen olemisen perustalta (Nancy 1996: 13). Tai hieman toisin muotoiltuna ja viitaten taas Heideggeriin: kirjoittaa uudestaan Olemisen ja ajan eksistentiaalisen analytiikan kanssaolemisen tai Mitseinin näkökulmasta (Nancy 1996: 118 , viite 1). Nancyn mukaan nimittäin olemisen mieli on vain jakamisessaan, mielekkyyden tila avautuu vain yhdessä, "meidän kesken", ja hänen keskeisin vastaväitteensä Heideggerille onkin se, että vaikka tämä eksplisiittisesti sanoo täällä-olemisen olevan "itsessään olemuksellisesti kanssaolemista" (Heidegger 2000b: 158), tosiasiassa kanssaoleminen jää Heideggerin analyyseissa alisteiseen asemaan (suhteessa Daseinin varsinaiseen itsenäolemiseen). Paitsi että tällä on mahdollisesti eettisesti ja poliittisesti tuhoisia seurauksia (kuten silloin kun "kanssa" korvautuu kansalla ja sen kohtalolla), tällöin jää myös epäselväksi, millä tavalla Mitsein itse asiassa on Daseinille olemuksellista tai konstitutiivista. (Nancy 1996: 117-118.) Tähän kysymykseen Nancy pyrkii singulaarisen pluraalisen olemisen ajattelullaan vastaamaan.

Nancy tiivistää kriittiset huomionsa yllättävällä tavalla. Hän toteaa, että koska Heidegger ei kiinnitä tarpeeksi huomiota kanssaolemiseen, häneltä jää huomaamatta, että olemisen mieli löytyy vain tietyn, hyvin omalaatuisen "kommunikaation" ulottuvuudesta. Tämä kommunikaatio ei Nancylle tarkoita merkitysten välittämistä, vaan se viittaa määrättyjä merkityssisältöjä edeltävään ja ne vasta mahdollistavaan mielekkyyden ulottuvuuteen, jossa kieli on ennen kaikkea sanojen puhuttelevuutta. ${ }^{6}$ Nancyn mukaan voitaisiin jopa sanoa, että se mikä tässä kommunikaatiossa on eettistä löytyy pikemmin faattiselta kuin semanttiselta tasolta - se sijoittuu siis siihen ulottuvuuteen, jossa pelissä on puhuttelun mahdollisuuden pitäminen auki, kun taas märätyn, lukkoonlyödyn merkityksen välit- 
täminen pikemminkin sulkee mahdollisen mielekkyyden tilan. (Ks. Nancy 1998: 60-62.) Niinpä Nancyn Heideggerille esittämissä "moitteissa" onkin viime kädessä kyse siitä, että tämän "alkuperäinen etiikka' ei ajattele vielä tarpeeksi vastuutaan omasta eks-positiostaan (avautumisestaan toiselle, maailmaan), joka kuitenkin muodostaa sen todellisen logiikan" (Nancy 1998: 62).

Kyse on siis filosofisen tekstin itsensä avautumisesta, altistumisesta tai olemisesta kohti maailmaa. Jos, kuten todettu, ontologia siinä merkityksessä kuin Nancy sen ymmärtää on aina jo eettisen suhteen avautumista ja vastuuta, aina jo mukana siinä mielen ulottuvuudessa, jota se tavoittelee sanomisessaan, tällöin ajattelun (ei-objektiivinen) kohde ikään kuin kääntyy takaisin siitä puhuvaan teokseen ja asettaa sille tiettyjä vaatimuksia. Mielenkiintoista on, että ajattelun (tai kirjoituksen) vastuu näyttäisi paikantuvan esityksen tai teoksen "muodon" tasolle. Nancy huomauttaa Etre singulier pluriel -teoksensa esipuheessa, että yritystä ajatella olemisen singulaarista pluraalisuutta ei enää käy sovittaminen ontologisen tutkielman muotoon. Kun kanssaoleminen - mielen jakaminen - otetaan vakavasti, filosofia ei voi enää teeskennellä olevansa neutraalia, subjektitonta, objektiivista. Mieli ei nimittäin piile filosofisessa diskurssissa, vaan siinä että tuo diskurssi on osoitettu toiselle. Ajattelu on puhuttelua, se on aina osoitettu toiselle (vaikka sitten vain sille toiselle minussa, johon jo Platonin mainitsema "sielun dialogi itsensä kanssa" viittaa). Ja lopulta se myös tulee toiselta, maailmasta ajattelu ei koskaan ole itseriittoista eikä spontaania. (Ks. Nancy 1996: 13-14.)

Jos siis mieli on puhuttelussa ja eettinen suhde avautuu pikemmin sanomisen tavassa kuin siinä, mitä sanotaan, kysymys kuuluukin, mitä singulaarisen pluraalisen olemisen ajattelu tällöin vaatii esitykseltään? Kyse ei selvästikään ole vain "muodon" ja "sisällön" yhteensovittamisesta - kuten jatkossa käy ilmi, Nancy pikemminkin dekonstruoi tämän vastakohtaparin. Sen sijaan olisi kysyttävä, kuinka (ontologian) kieli tässä siirtyy merkityksen järjestyksestä sitä edeltävään puhuttelevuuden ulottuvuuteen, kuinka kirjoitus kantaa vastuun kaikki välittämänsä merkitykset ylittävästä mielestä? Ennen kuin voimme yrittää etsiä vastausta näihin kysymyksiin, on kuitenkin syytä pysähtyä hetkeksi tarkastelemaan sitä, millaista on tämä kanssaoleminen, joka asettaa ajattelulleen näin ankaria vaatimuksia.

Nancyn ontologian perusväite on siis se, että "oleminen" ei ole yksi: olevien moneus ei ole sattumaa vaan välttämätöntä. Olemisen monikollisuuden aksiooma on ymmärrettävä kaikessa radikaaliudessaan: oleminen ei ole yksi perimmäinen substanssi, josta kaikki lukuisat olevat olisivat osallisia, eikä se ole myöskään jonkinlainen kaikkien olevien yhteenlaskun lopputulema (Nancy 1996: 120). Sen sijaan olemisen olemus on kanssaoleminen - missä "kanssa" (l'avec) muodostaa olemisen eikä suinkaan ole jotain olemiselle ulkoista, sattumanvaraista yhteenkerääntymistä, jotain olemiseen jälkikäteen lisättyä (Nancy 1996: 50). Voisi jopa sanoa, että oleminen on vain tämä "kanssa".

Tämän olemisen olemuksellisen moneuden ajattelussa filosofia on kuitenkin Nancyn mukaan epäonnistunut aina meidän päiviimme asti. Olemista tavataan ajatella yhtenä, jonka tuolla puolen "on" vain sen korrelaatti ei-oleminen (Nancy 1996: 100). Moneus saa sijaa vasta, kun ajatellaan "sosiaalista olemista", kaiken kaikkiaan toissijaisena pidettyä kategoriaa. "Sosiaalisen olemassaolon" kysymyksestä on kuitenkin Nancyn mukaan nyt tultava ontologian ensimmäinen kysymys - suuri ontologinen kysymys itse. (Nancy 1996: 78.) On siis käännettävä nurin ontologisen tutkimuksen rakenne, otettava uusi lähtökohta. Enää ei voi lähteä liikkeelle olemisesta sellaisenaan tai subjektista, joka tätä olemista tavoittelee, vaan ainoastaan olemisen jakamisesta. (Ks. Nancy 1996: 50.)

Kanssaolemisen ontologian ensimmäinen premissi onkin, että - toisin kuin yksiköllinen 
sana "oleminen" antaa ymmärtää - olemista ei voida olettaa ennakolta, se ei ole mitään mikä edeltäisi olevien olemassaoloa tai perustaisi sen. Päinvastoin, "oleminen yleensä" (lainausmerkeissä, sillä oleminen ei Nancylle nimenomaan ole mikään yleiskategoria) on ajateltavissa vasta toinen-toistensa-kanssa-olemisesta lähtien. (Nancy 1996: 77-78.) Olemisen (perustaton) perusta on olevien moneudessa. Yksi ainoa oleva olisi suorastaan ristiriitainen käsite, se olisi oma perustansa ja alkuperänsä, mykkä ja itseensä sulkeutunut, eikä se siis lainkaan olisi. Nancylle oleminen ei nimittäin ole jonkinlainen staattinen olotila, vaan se on kääntymistä ulos itsestä, olemista kohti (maailmaa, toisia, itseä), suhdetta ja tilallistumista. (Nancy 1996: 30-31; Nancy 1993: 109; Lindberg 1998: 83-84).

Kanssaoleminen on siis jotain aivan muuta kuin autonomisten, itseriittoisten subjektien välinpitämätöntä rinnakkaisuutta, astumista sisäisyydestä maailmaan kuin ulos kotoaan. Muiden olemassaolo ei ole ulkoista minun olemassaololleni, se ei ole mitään siihen jälkikäteen lisättyä. Jokaista olevaa määrittää olemisessaan oleminen muiden kanssa, ainutkertaisuus ja monikollisuus kietoutuvat yhteen erottamattomasti. $^{7}$

Tästä olemuksellisesta moneudesta seuraa, että olemisen mieli on sekin vain tässä moneudessa, siinä kuinka me altistumme toinen toisillemme. ${ }^{8}$ Tästä tosiasiasta kertoo omalla tavallaan - joskin tiedostamattaan - se mekaanisesti toisteltu valitus, että arvot ovat menettäneet merkityksensä, kukaan ei enää usko mihinkään korkeampaan totuuteen, yhteisöllisyys rapautuu, (kulutus)yhteiskunta on pelkkä tyhjä spektaakkeli ja niin edelleen. Se että olemassaoloa ei enää voida perustaa millekään sille ulkoiselle (transsendentille) merkitykselle paljastaa kaikessa alastomuudessaan ainutkertaisten olevien olemisen yhdessä vailla mitään olemuksellisia siteitä. ${ }^{9}$ Jos, kuten väitetään, "meillä ei enää ole mieltä", tämä johtuu Nancyn mukaan siitä että me olemme mieli. (Nancy 1996: 19.)

Miten tämä julistus tulisi ymmärtää? Kyse ei ole siitä, että me olisimme mielen sisältö tai täyttymys, että ihminen olisi olemisen, luonnon tai historian mieli (päämäärä tai viimekätinen arvo). Päinvastoin, juuri tällaiseen "ihmiselle" annettuun merkityssisältöön turvaaminen on nyt osoittautunut mahdottomaksi. Sen sijaan "me olemme mieli" sinä ulottuvuutena, jossa merkityksiä (vaikkapa sanalle "ihminen" annettuja merkityksiä) voidaan tuottaa ja välittää. Olennaista tässä on huomata se, että mieli on vain jakamisessaan, se on omaa kommunikaatiotaan tai kiertoaan "meidän" välillämme, yhdeltä toiselle - mutta, kuten sanottu, tämä ei tarkoita jonkin määrätyn merkityssisällön välittämistä eteenpäin. Millä tahansa merkityssisällöllä voi olla mieltä vain kommunikoituna (vaikka sitten vain minulta minulle itselleni), ja mieli on juuri tässä kommunikaation tosiasiassa, siinä että se on osoitettu toiselle. (Ks. Nancy 1996: 19-20.) Jos voitaisiin ajatella kieltä, josta on poistettu kaikki merkitys, jäljelle jäisi vielä sanojen osoittaminen toiselle, toisen tähden: tuo puhuttelu olisi puhtaan kanssaolemisen tila.

Tällaisen yhdessäolemisen ajattelussa filosofia Nancyn mukaan siis vielä kompastelee. Kyse ei kuitenkaan ole siitä, että sen tarkka määritelmä pitäisi ottaa tulevaisuuden tavoitteeksi, sillä se "me”, josta Nancy puhuu, ei ole mikään uusi ajattelun kohde, joka pitäisi identifioida, määritellä ja esittää. Tehtävä on itse asiassa aivan päinvastainen:"me" pitäisi kyetä sanomaan niin, että se ei ole oman representaationsa subjekti, vaan puhdasta altistumista tässä sanomisessa. "Meidän" tai kanssaolemisen ajattelu ei ole representatiivista vaan - jälleen kerran - eetos ja praksis. (Ks. Nancy 1996: 93-94.)

Kun nyt ollaan taas päästy tähän pisteeseen, voisi tietenkin kysyä, mikä asema ontologialla tässä kuviossa itse asiassa enää on. Jos ensisijaista on toimivan, eettisen suhteen avautuminen olemisen mieleen, yhdessä-ilmenemisen näyttämöllepano ja altistuminen (jota Nancyn mukaan sitä paitsi tapahtuu kaiken aikaa, joskin meidän on keksittävä sen tapahtuma joka kerran uudestaan), jääkö olemisen luonnetta kos- 
keville, filosofisille väittämille enää sijaa? Kyllä: Nancylle ei ole olemassa etiikkaa ilman ontologiaa (ja kääntäen). Alustavasti voisi sanoa, että kyse on ikään kuin saman tekstin kahdesta eri tasosta. Yhtäällä on tekstin merkityssisältö, olemista koskevat väitteet tai se, mitä siinä sanotaan; toisaalla sen avautuminen kohti maailmaa sanomisessaan, se että se puhuttelee..$^{10}$ Tai kuten Nancy sanoo, ontologia ja etiikka ovat erottamattomia: etiikka asettaa alttiiksi sen, minkä ontologia jäsentää (Nancy 1996: 123).

Edellä jo mainitsin Nancyn ajattelevan, ettei ontologiaa (sanaa tai asiaa) voi yksinkertaisesti korvata etiikalla. Syy tähän oli se, että jos etiikka syrjäyttää ontologian, on vaarana unohtaa se, että oleminen itsessään on mieltä tai mielen vetoomus. Mieli ei ole mitään "olemisen karkealle tosiasialle" ulkoista - pikemminkin mieli on siinä, ettei ole mitään itsessään mieletöntä olemisen karkeaa tosiasiaa (Nancy 1996: 20). Silti olemisen mieli ei ole välittömästi annettu - ja enemmänkin, se ei ole edes periaatteessa meidän saavutettavissamme, omittavissamme. Juuri tässä mielen saavuttamattomuudessa piilee Nancyn mukaan etiikan mahdollisuusehto. Vastuu mielestä tarkoittaa sille altistumista, ei haltuunottoa. Ja erityisesti vastuullinen vastaaminen mielen vetoomukseen edellyttää sitä, ettei olemiselle myöskään yritetä antaa mitään ikään kuin sen tuolta puolen löytyvää mieltä. (Nancy 1998: 43-44). Juuri tähän Nancyn mukaan kuitenkin helposti sorrutaan, jos etiikalle annetaan etusija ontologiaan nähden. Ja siksi hän korostaa, että etiikka ei voi olla ontologiasta riippumatonta, että vain ontologia voi olla etiikkaa ristiriidattomalla tavalla. Tämä on näet ainut mahdollisuus tehdä oikeutta itsessään oikeuttamattomalle singulaariselle pluraaliselle olemiselle, välttää kanssaolemisen - toisten - korvautuminen transendentilla Toisella tai jollakin muulla periaatteella, joka sitten asetetaan mielen alkuperäksi. (Nancy 1996: 39-40, 69.) (Ja toisaalta, kuten varmasti on jo käynyt selväksi, ei ole myöskään niin, että ontologia tulisi ensin, että meillä olisi ensin tieto tutki- muksen kohteesta ja vasta sitten mahdollisuus luoda siihen suhde. Kyseessä kun ei ole mikään "kohde", josta voisi olla puhtaan teoreettista tietoa: ajattelu on itsessään altistumista, vastaamista mielelle ja mielestä.)

Ontologia on siis välttämätöntä, mutta millaista se voi näissä olosuhteissa olla? Kuinka esittää filosofinen väite siitä, mikä vasta mahdollistaa väitteiden esittämisen? Siitä, mitä ei voi esittää olevana olevien joukossa, koska se nimenomaan ei ole oleva olevien joukossa vaan pikemminkin itse tämä "joukossa", "kanssa", "välillä", "kesken"? (Ks. Nancy 1996: 110.) Tehtävä kuulostaa mahdottomalta, mutta Nancy tunnustaa sen välttämättömyyden. Mieleen ei nimittäin ole välitöntä pääsyä, se ei ole mitään alkuperäistä täyteyttä, jonka voisi tavoittaa intuitiolla tai johon voisi sulautua eletyssä kokemuksessa tai jonkinlaisessa ekstaasissa. Mieli tulee, kuten Nancy sanoo, kosketettavaksi ainoastaan merkityksen rajoilla. Vaikka mieli ei tule merkityksellisen kielen piiriin, sitä ei myöskään ole olemassa siitä riippumatta.

Siksi filosofian paradoksaalinen tehtävä, sen praksis, muodostuu kirjoittamisen ja lukemisen työstä, joka tuo esiin sen pisteen, jossa kaikki merkitsevään kieleen nojaavat tuotokset - mukaan lukien sen omat - väistämättä epäonnistuvat (Lacoue-Labarthe \& Nancy 1997: 91). Mutta tämä epäonnistuminen on välttämättä käytävä läpi, koska kuten Nancy korostaa, siihen mikä ylittää merkityksen järjestyksen ei ole muuta tietä kuin merkityksellinen kieli. Ainoastaan kieli - tässä tapauksessa filosofian kieli, joka muotoilee teesin olemisen singulaarisesta pluraalisuudesta - voi ehtymisensä tai murtumisensa hetkellä osoittaa kohti sitä mitä se ei voi esittää (vrt. Nancy 2004: 66). Jos Nancy siis viekin kielen (ranskan kielen ja filosofian kielen, metafysiikan perinteeltä saamamme kielen) aina äärirajoilleen asti, hän ei kuitenkaan pyri kielen tuolle puolen. Rajan toisella puolen ei nimittäin ole mitään, toista kieltä meillä ei ole. ${ }^{11} \mathrm{Ei}$ ole olemassa mitään täydempää (vaikkapa runollista) kieltä, jossa mieli olisi välittömästi läsnä. Ja jos sille, mitä 
Nancy yrittää sanoa, ei ole kieltä, se ei voi tulla sanotuksi kuin tekstin liikkeessä ja jännitteissä, juuri kielen rajojen tullessa vastaan (vrt. Fynsk 1991: ix). Lopulta kyse on siitä, mitä merkitykset ylittävä mieli tekee filosofiselle diskurssille, joka sitä tavoittelee, ja kirjoituksen vastuusta tätä ylimäärää kohtaan (Nancy 1993: 37). ${ }^{12}$

Tämä mielen ylimäärän kirjoitukselle heittämä haaste näkyy vaikkapa siinä, kuinka Nancy yrittää sanoa "kanssan" (l'avec) ulottuvuuden sellaisenaan. Hän pahoittelee sitä, että tämä johtaa varsin kömpelöihinkin muotoiluihin, mutta toteaa samaan hengenvetoon, ettei liene lainkaan sattumaa, että kieli ei tunnu taipuvan ilmaisemaan "kanssaa", sillä se on puhuttelu itse tai sanojen toiselle osoittamisen tila, ei vain aihe muiden joukossa (Nancy 1996: 13). Tällöin se mitä yritetään sanoa ei nimittäin periaatteessakaan voi tulla sanotuksi, koska se on itse sanomisen mahdollisuus. Tai tarkemmin sanoen se ei voi tulla sanotuksi väitelauseen muodossa, siis märirtellyksi ja esitetyksi jonkin ominaisuutensa perusteella. Sillä lopulta, kaikesta huolimatta, sen mitä ei voi esittää voi vain sanoa - siis altistaa jakamiselleen. Näin tapahtuu vaikkapa silloin, kun Nancyn käyttämät kieliopinvastaiset muotoilut - jotka saattavat kyllä olla pökerryttäviä mutta tuskin kömpelöitä, Nancyn kieli on todella hienovireistä - vievät lukijan merkityksellisen kielen rajoille, joilta avautuu jotain joka ei ole taas uusi merkitys vaan pikemminkin kohtaaminen. Sillä vaikka kieli tässä törmää rajoihinsa, me Nancyn lukijat ymmärrämme, mihin hän pyrkii - tai ehkä ymmärrämme väärin, sillä ei tässä ole niin väliä, sillä ensisijaista ei ole merkityksen siirto lähettäjältä vastaanottajalle - mutta ymmärrämme joka tapauksessa, että tässä yrityksessä on jotain mieltä.

Tai paremminkin mieli syntyy tässä kohtaamisessa kirjoittamisen ja lukemisen yhteisön kesken, puhuttelussa ja vastaamisessa. Edellä kävi ilmi, ettei perinteisen ontologisen tutkielman muoto Nancyn mukaan enää aja asiaansa: jos "olemista" ei enää voida ajatella yksikössä, myöskään "olemisen tiede" ei enää voi puhua kohteestaan yksikön kolmannessa persoonassa - mutta lopulta myös sen itsensä oleminen yksikössä joutuu kyseenalaiseksi, ontologiakin on moniäänistä, logos on dialogia. (Vrt. Nancy 1996: 53, 110.) Mieli - joka, muistetaan Nancyn sanat,"me olemme" - ei ole kenenkään omittavissa, ei kenenkään hallussa, se ei löydy yhdestäkään filosofisesta teoksesta - vaan ainoastaan jakamisestaan. Se että mieli paikantuu jakamiseensa tarkoittaa kuitenkin myös sitä, että toisaalta mieltä ei ole olemassa missään singulaaristen artikulaatioidensa tuolla puolen. ${ }^{13}$ Jotta mieltä olisi, jonkun on siis annettava sille äänensä. Tässä törmätään taas ylitsepääsemättömältä vaikuttavaan ongelmaan: jos mielen jakamisen yhteisö esitetään itselleen (filosofisessa, taiteellisessa tai poliittisessa) teoksessa, jakamisen ja yhdessä-olemisen tila kasvaa umpeen; ja jos taas puhuttelun tila jätetään oman onnensa nojaan, lausumatta, mielekkyyden ulottuvuus painuu yhtä lailla kasaan ja kanssaoleminen romahtaa pelkäksi rinnakkaisuudeksi. (Nancy 2004: 227-228, ks. myös Lindberg 1998: 79-83.)

Mikä siis eteen, onko tähän pattitilanteeseen ratkaisua? Voisi melkein sanoa, että tässä tapauksessa epäonnistuminen on onnistumisen edellytys. Teos, joka onnistuisi identifioimaan, märittelemään ja esittämään kanssaolemisen mielen, tulisi samalla tuhonneeksi sen, sillä se ei antaisi mielelle tilaa tulla sanotuksi toisin. Mielen artikulaatio ei saa täydellistyä kokonaisuudeksi tai systeemiksi, teokseksi joka sulkeutuu johdonmukaisesti kehitellyn argumentin tuottamiin loppupäätelmiin. Tämä teoksen purkautuminen (désceuvrement) on osaltaan vastuuta mielen jokaiseen merkityssysteemiin nähden muodostamasta ylimäärästä. Kirjoitus - ja Nancyn mukaan tässä "ontologia osoittautuu kirjoitukseksi" - ei pyri käsittämään, ottamaan haltuun asiaansa, vaan kuten Nancy myös sanoo, kurottaa koskettamaan sitä; kirjoitus ei yritä sulauttaa mieltä itseensä vaan tahdikkaasti säilyttää eron niin, että se mitä kosketaan jää vielä kontaktissakin vieraaksi (Nancy 2010: 38-39). 
Ja toisaalta kirjoitus jää avoimeksi myös siinä mielessä, että se asettuu itse alttiiksi siinä puhuttelun ulottuvuudessa, jossa mieli saa lukemattomat artikulaationsa. Niinpä myös keskeytys, se jokin joka saa teoksen logiikan purkautumaan ja estää sitä sulkeutumasta itseensä, on loppujen lopuksi peräisin tästä ulottuvuudesta, toiselta tai toisilta - tai "sinältä", jota kirjoitus puhuttelee (ks. Derrida 2000: $324,326)$. Kirjoitus ei nimittäin ole yksiselitteisesti sen jonkun hallussa, joka sen on allekirjoittanut: jokin vääntää sen sijoiltaan, saa sen purkautumaan ja fragmentoitumaan, pakottaa aloittamaan aina alusta. Mutta tämä epäonnistuminen on, kuten sanottu, myös onnistumisen ja lopulta eettisen suhteen itsensä edellytys. Kirjoitus ottaa vastuun mielestä asettumalla alttiiksi sille jollekin, joka ei koskaan voi olla vain sen symmetrinen vastinkappale, välittäjä takaisin itseen palaamisen liikkeessä (ks. Derrida 2000: 317-318, 326).

Edellä totesin, että ontologian ja etiikan osumisessa yksiin on tietyllä tapaa kyse saman tekstin kahdesta eri tasosta: yhtäällä on se, mitä sanotaan, toisaalla se, kuinka se sano-

\section{VIITTEET}

1. Kreikan sana èthos, josta termi 'etiikka' polveutuu, tarkoittaa muun muassa tapaa, (moraalista) luonnetta, taipumusta ja vakiintunutta paikkaa. Prāksis, joka puolestaan on monien käytäntöä tarkoittavien sanojen kanta (vrt. esim. suomen' praktiikka') merkitsee muun muassa (erityisesti inhimillistä) toimintaa, harjoitusta ja käytöstä. (Liddell \& Scott 1940, hakusanat èthos ja praxis.)

2. Taskufacta fllosofian sanakirja, hakusanat "etiikka" ja ”ontologia". Ks. myös esim. Audi (toim.) 1999.

3. Tällaisessa ajattelumallissa on siis vielä voimissaan aristoteelinen inhimillisten aktiviteettien (ja niitä vastaavien tiedonlajien) jako tuotannollisiin, käytännöllisiin ja teoreettisiin toimintoihin (poiēsis, prāksis ja theōria). Siinä missä tuotannolliset taidot tähtäävät tekemisestä erilliseen lopputulemaan, käytännöllisten päämäärä on toiminnassa itsessään ja teoreettinen ajattelu puolestaan tavoittelee totuutta. (Ks. esim. Aristoteles, Metafysiikka: 1025b; Aristoteles, Nikomakhoksen etiikka: 1094a.) taan tai lopulta se, että se sanotaan, osoitetaan toiselle. Kyse ei kuitenkaan ole perinteisestä muoto-sisältö-erottelusta: ei ole niin, että olisi erikseen asian kova ydin ja sen päälle liimatut retoriset tehokeinot, lukijan puhuttelu pelkkänä tyylikeinona. Lopulta "muoto" ja "sisältö" eivät tässä ole erotettavissa toisistaan. Sitä mitä Nancy sanoo, ei voi sanoa kolmannen persoonan väitelauseessa, vaan se on sanottava toiselle, sen voi ilmaista vain kutsussa tai puhuttelussa (vrt. Derrida 2000: 317-318). Nancylle ajattelun todellinen logiikka on siinä, kuinka se asettuu alttiiksi, avautuu kohti maailmaa, ja niinpä myös sen omin vastuu koskee mielen jakamisen, kanssaolemisen tilaa. Ontologian eetos ja praksis näkyy jatkuvassa siirtymässä teesistä puhutteluun, huolenpidossa tuosta mielekkyyden tilasta.

Näin se ontologia, jota Nancy Etre singulier pluriel -teoksessaan kehittelee, ei ole niinkään vastaus kysymykseen olemisen mielestä, vaan se pyrkii vastaamaan olemisen mielelle pitämällä auki sen tilan, jossa tämä kysymys voi nousta esiin yhä uudelleen ja jossa sen pakottavuuden voimme itse kukin tuntea.

4. Nancyn aiheesta kirjoittama teksti - joka on alun perin laadittu erästä etiikan ja moraalifilosofian sanakirjaa varten (Canto-Sperber [toim.] 1996) - on suomennettu nimellä Heideggerin "alkuperäinen etiikka"(Nancy 1998) ja löytyy myös teoksesta Nancy 2001.

5. Heidegger 2000a: 52-53, 95-96. Todettakoon tässä, ettei Nancy lainkaan jaa Heideggerin inhoa tekniikkaa kohtaan. Nancylle tekniikka pikemminkin tuo ilmi totuuden meidän maailmastamme, josta ajatus lineaarisesta edistyksestä kohti lopullista päämäärää samoin kuin sekä transsendentti että immanentti merkitys ovat kadonneet ja jossa ruumiit altistuvat toinen toisilleen vailla mitään perustaa. Tekniikka ei vieraannuta meitä jostakin (kuvitteellisesta) alkuperäisestä läsnäolosta, vaan se on alkuperäistä välitystä tai proteettisuutta, tilallistumista ja jakamista. (Ks. esim. Nancy 2010: 64, 93-97; Derrida 2000: 129-148.) Samoin ajatus metafysiikan ylittämisestä, siitä että sen tuolta tai tältä puolen löytyisi jotain 
täydempää, alkuperäisempää, on sinänsä Nancylle vieras: ajatus jostakin menneestä ja nyt kadotetusta merkityksestä, joka meidän täytyisi löytää uudelleen, on hänelle pikemminkin metafyysinen ajatus par excellence, ajatus jolle koko merkityksen halu perustuu. Sen sijaan voidaan kyllä ajatella, että pisteestä johon nyt olemme päätyneet avautuu uudenlainen suhde perinteeseen itseensä sen sisältä käsin. (Ks. Nancy 1986: 68-70.)

6. Kieli ei toki Heideggerillekaan ole ensi sijassa kommunikaatioväline - tällainen välineellinen tulkinta nimenomaan estää hänen mukaansa näkemästä kielen todellista luonnetta. Heidegger sanoo, että kieli on "olemisen talo", toisin sanoen juuri kielessä toteutuu ihmisen ja olemisen suhde tai "ajattelussa oleminen tulee kieleen" (Heidegger 2000a: 51). Nancyn kritiikki koskeekin sitä, että Heidegger unohtaa "kommunikaation" kielen alkuperäisen puhuttelevuuden merkityksessä. Erityisesti kun Heidegger antaa "ajattelijalle" ja "runoilijalle" etusijan olemisen kieleen tuomisessa, saattaa vaikuttaa siltä kuin näillä hahmoilla olisi kyky antaa olemiselle merkitys tai saavuttaa se välittömästi omassa "hiljaisessa sanomisessaan", kun taas Nancy painottaa sitä, että mieli syntyy vain meidän altistuessamme yhdessä toinen toisillemme (Nancy 1998: 61-62; vrt. Heidegger 2000a: 51).

7. Nancy kuvaa "jotakuta" tai singulaaria seuraavasti: Jokainen"joku" on kyllä ehdottoman singulaarinen, mutta tämä ainutkertaisuus edellyttää singulaarien moneutta - ne eroavat toisistaan, eivät jostakin arkkityypistä tai yleismuodosta. Näin siis ainoastaan olemisen moneus (singulaarisuuden jakaminen) erottaa singulaarin absoluuttisesti toisista. Mutta singulaari on myös kuka tahansa, sillä jokainen on aivan yhtä singulaarinen kuin kuka tahansa toinenkin. Se mikä singulaareille on yhteistä on niiden yhteismitattomuus - ja tällä paradoksaalisella tavalla ne ovat vaihdettavissa toisiinsa. Ja lopulta, jokaisen singulaarin läsnäolon tapa on"eskatologinen” siinä merkityksessä kuin jokainen (ekaston) oli Aristoteleelle viimeinen, äärimmäinen (eskbaton). Yhden singulaarin altistuessa kaikki altistuu. Sen sijaan singulaari ei ole partikulaari: se ei voi olla osa jostakin luokasta, sillä se on itse se tapahtuma, jossa siirrytään pois luokittelun mahdollistavasta tiedon ja logiikan järjestyksestä. Eikä se myöskään ole yksilö, jos yksilö ymmärretään itseriittoiseksi ja itsetietoiseksi, autonomiseksi instanssiksi, joka edeltää mahdollisia suhteita muihin individeihin. (Nancy 1993: 115-120.)
8. Ja emme vain me ihmiset, vaan aivan kaikki olevat. Mieli ei rajoitu ihmiseen, Daseinin "ontis-ontologinen erityisasema" (vrt. Heidegger 2000b: 32-35) ei Nancyn mukaan suinkaan tarkoita sitä, että ihmisellä olisi yksinoikeus johonkin todelliseen olemiseen,jonka köyhempiä muunnelmia muut olevat edustaisivat (Nancy 1996: 36-37). En kuitenkaan pysty tässä tarkastelemaan asiaa lähemmin.

9. Sinänsä ajatus kadotetusta merkityksestä,joka meidän olisi löydettävä uudestaan päästäksemme eroon hajaannuksesta ja löytääksemme yhteisöillemme taas vakaan perustan, ei ole mitään uutta, ja Nancy on tästä hyvin tietoinen. Mutta nyt olemme tilanteessa, jossa yhteisön jäsenet toisiinsa liittävän (pyhän) siteen katkeamisen paljastama kanssaoleminen nousee esiin yhä vastaansanomattomammin. (Ks. Nancy 2004; Nancy 1986.)

10. Tässä on syytä mainita Emmanuel Levinasin erottelu sanomisen (le Dire) ja sanotun (le Dit) välillä. Siinä missä sanottu viittaa puheen sisältöön, määrättyyn merkitykseen, väitelauseisiin, joiden totuusarvo on mahdollista määrittää - ulottuvuuteen, jossa Toinen lopulta aina palautetaan samaan, partikulaarinen alistetaan universaaleille kategorioille - sanomisessa on kyse minun altistumisestani Toiselle ja lopulta äärettömästä vastuustani tämän Toisen edessä. Sanominen kertoo siitä, että puheeni on aina osoitettu Toiselle, ja tässä liikkeessä Samasta kohti Toista se muodostaa kielen eettisen ylijäämän, joka ei ole tematisoitavissa eikä ymmärrettävissä ja joka näin keskeyttää sanotun (vaikkapa filosofisen diskurssin). Tämä on toki vain yksinkertaistettu esitys; aiheesta tarkemmin ja näiden kahden "tason" monimutkaisesta yhteenkietoutumisesta ks. Levinas 2006, erit. s. 16-20, 64-86 sekä Critchley 2007.

11. Toisen kielen mahdottomuudesta ks. esim. Derridan kirjoitus "Violence et métaphysique" (Derrida 2006: 117-228), jossa tämä kiinnittää huomiota erityisesti siihen, kuinka jokainen yritys ylittää metafysiikka joutuu tässä yrityksessään turvautumaan kiistämäänsä metafysiikan kieleen.

12. Huomion kääntyminen kieleen ja kirjoitukseen, filosofian suhteeseen omaan esitykseensä, ei toki ole vain Nancyn ajattelun erityispiirre. Päinvastoin, Nancy itsekin huomauttaa, että tässä ei ole mitään uutta, että filosofia on vähintäänkin Nietzschestä lähtien ollut pulassa muotonsa kanssa, joutunut kohtaamaan tyylin kysymyksen uudella tavalla (ks. Nancy 1996: 13). Yleisem- 
minkin on käynyt selväksi, että filosofian ikiaikainen haave"läpinäkyvästä"kielestä,joka ikään kuin haihtuisi viittauskohteensa tieltä ja näyttäisi sen puhtaudessaan, on juuri sitä mitä se on, pelkkä haave. Filosofiankin kieli on aina kirjoituksen työn ja myös sanojen itsensä sattumanvaraisuuden, hämäryyden ja materiaalisuuden saastuttamaa.(Ks. esim.Lacoue-Labarthe 1979: 7-30.) Ranskalaisen filosofian "kielellisestä käänteestä", rajankäynnistä kirjallisuuden kanssa ja filosofian kirjoittamisen tavan tai tyylin mullistuksesta viime vuosisadan jälkipuoliskolla ks. esim. Badiou 2004.

13. Mielen ja sen artikulaatioiden suhde noudattaa siis vastaavaa rakennetta kuin olemisen ja olevien (ja lopulta ne käyvät yksiin, sillä Nancylle oleminen on itsessään mieltä). Sekä oleminen että mieli piilevät vain ainut-

\section{KIRJALLISUUS}

Aristoteles (1989) Nikomakhoksen etiikka. Suomentanut Simo Knuuttila. Helsinki: Gaudeamus.

Aristoteles (1990) Metafysiikka. Suomentaneet Tuija Jatakari, Kati Näätsaari ja Petri Pohjanlehto. Helsinki: Gaudeamus.

Audi, Robert (toim.) (1999) The Cambridge Dictionary of Philosophy. Cambridge: Cambridge University Press.

Badiou, Alain (2004)"Panorama de la philosophie française contemporaine". http://www.lacan.com/badfrench. htm

Canto-Sperber, Monique (toim.) (1996) Dictionnaire d'éthique et de philosophie morale. Paris: PUF.

Critchley, Simon (2007/1992) The Ethics of Deconstruction. Derrida and Levinas. Delhi: Motilal Banarsidass.

Derrida, Jacques (2000) Le toucher, Jean-Luc Nancy. Paris: Galilée.

Derrida, Jacques (2006/1967) L'écriture et la différence. Paris: Seuil.

Fynsk, Christopher (1991) "Foreword: Experiences of Finitude". Teoksessa Nancy, Jean-Luc, The Inoperative Community. Kääntäneet Peter Connor, Lisa Garbus, Michael Holland ja Simona Sawhney. Minneapolis \& Oxford: University of Minnesota Press. vii-xxxv.

Heidegger, Martin (2000a) Kirje "bumanismista" \& Maailmankuvan aika. Suomentanut Markku Lehtinen. Helsinki: Tutkijaliitto.

Heidegger, Martin (2000b/1927) Oleminen ja aika. Suomentanut Reijo Kupiainen. Tampere: Vastapaino. kertaisissa"ilmentymissään"- mutta pitää muistaa, ettei näiden ilmentymien taustalta löydy mitään salaisuutta, ei mitään itsenäistä substanssia. Ei ole niin, että meillä olisi yhteinen mieli, joka sitten vain saisi erilaisia muotoiluja. Ja toisaalta äänten jakaminen, olemisen mielen singulaariset artikulaatiot, ei myöskään viittaa mihinkään pluralismiin tai kulttuurirelativismiin. Nämä kun liikkuvat pikemminkin identiteetin ja arvojen tasolla, jolla jokin tietty ryhmä jakaa jonkin perustan tai olemuksen ja vastaavasti sulkee muut ulos. "Me", johon Nancy mielen paikantaa, ei sen sijaan sulkeudu mihinkään identiteettiin, mikään ei yhdistä"meitä" toisiimme. Mielen jakaminen "meidän kesken" on se ulottuvuus, joka vasta mahdollistaa sen, että jokin ryhmä voi omaksua tietyt arvot ja jokin toinen ryhmä toiset.

Lacoue-Labarthe, Philippe (1979) Le sujet de la philosophie (Typographies 1). Paris: Aubier-Flammarion.

Lacoue-Labarthe, Philippe \& Nancy, Jean-Luc (1997) Retreating the Political. Toimittanut Simon Sparks. London: Routledge.

Levinas, Emmanuel (1996) Etiikka ja äärettömyys. Keskusteluja Philippe Nemon kanssa. Suomentaneet Outi Pasanen ja Antti Pönni. Helsinki: Gaudeamus.

Levinas, Emmanuel (2006/1974) Autrement quêtre ou audelà de l'essence. Paris: Le Livre de Poche.

Liddell, Henry George \& Scott, Robert (1940) A GreekEnglish Lexicon. Oxford: Clarendon Press.

Lindberg, Susanna (1998) Filosofien ystäryys. Helsinki: Tutkijaliitto.

Nancy, Jean-Luc (1986) L'oubli de la philophie. Paris: Galilée.

Nancy, Jean-Luc (1993) Le Sens du monde. Paris: Galilée. Nancy, Jean-Luc (1996) Etre singulier pluriel. Paris: Galilée.

Nancy,Jean-Luc (1998) Heideggerin "alkuperäinen etiikka". Suomentanut Kaisa Sivenius. Helsinki: Loki-Kirjat. Nancy, Jean-Luc (2001) La pensée dérobée. Paris: Galilée. Nancy, Jean-Luc (2004/1986) La communauté déscuvrée. Paris: Christian Bourgois.

Nancy, Jean-Luc (2010) Filosofin sydän. Suomentaneet Susanna Lindberg, Elia Lennes ja Kaisa Sivenius, toimittanut Sami Santanen. Helsinki: Gaudeamus.

(1999) Taskufacta filosofian sanakirja. Helsinki: WSOY. 